This is an electronic reprint of the original article. This reprint may differ from the original in pagination and typographic detail.

Author(s): Kannampuzha, Merie Joseph; Suoranta, Mari

Title: $\quad$ Bricolage in the marketing efforts of a social enterprise

Year: $\quad 2016$

Version:

Please cite the original version:

Kannampuzha, M. J., \& Suoranta, M. (2016). Bricolage in the marketing efforts of a social enterprise. Journal of Research in Marketing and Entrepreneurship, 18(2), 176196. https://doi.org/10.1108/JRME-07-2015-0039

All material supplied via JYX is protected by copyright and other intellectual property rights, and duplication or sale of all or part of any of the repository collections is not permitted, except that material may be duplicated by you for your research use or educational purposes in electronic or print form. You must obtain permission for any other use. Electronic or print copies may not be offered, whether for sale or otherwise to anyone who is not an authorised user. 


\title{
Bricolage in the marketing efforts of a social enterprise
}

\author{
Merie Joseph Kannampuzha and Mari Suoranta \\ Jyvaskyla University School of Business and Economics, University of Jyvaskyla, Jyvaskyla, \\ Finland
}

DOI: http://dx.doi.org/10.1108/JRME-07-2015-0039

\section{Structured Abstract}

Purpose - The article aims to understand how resource constraints are addressed in the development of a marketing strategy by a social enterprise.

Methodology - The authors have used an in-depth case study of collaboration between a Finnish university and an Indian social enterprise as the methodology for our research in which the data were collected over a period of two years. The data involve semi-structured interviews, field notes and student reports.

Findings - The authors propose bricolage as a method of marketing ingenuity in resource-constrained social enterprises. Network bricolage and entrepreneurship education bricolage were identified as two mechanisms adopted to address resource constraints in the early stage of the development of a social enterprise.

Research limitations/ implications - Network bricolage is a type of bricolage in which an entrepreneur utilizes existing personal and professional networks as a resource at hand. Whereas networking and resource leveraging imply that the founders of an organization pursue resources from previously unknown people, network bricolage involves already known contacts of the entrepreneur. Further studies need to be conducted to test the applicability of network bricolage among a variety of small and medium-sized enterprises and start-ups. Bricolage could be explored in more detail as an alternative to resource leveraging to understand the marketing activities of social businesses in their initial stages.

Practical implications - Another type of bricolage that the authors observed was entrepreneurship education bricolage. A combination of students, business mentors and university resources such as faculty members was utilized as an ingenuity mechanism to develop creative solutions for a shortage of marketing resources.

Originality/value - The theoretical framework of entrepreneurial bricolage is applied in the context of the marketing of a social enterprise.

Keywords Entrepreneurial marketing, Bricolage, Social enterprise, Resources, Network bricolage

Paper Type Research Paper

'This article is $\odot$ Emerald Group Publishing and permission has been granted for this version to appear here (please insert the web address here). Emerald does not grant permission for this article to be further copied/distributed or hosted elsewhere without the express permission from Emerald Group Publishing Limited.'

DOI: http://dx.doi.org/10.1108/JRME-07-2015-0039 


\section{Introduction}

This paper contributes to the literature on entrepreneurial marketing in the context of social enterprises. Social enterprises are considered a possible future strategy to address a previously untapped and unrecognized market in developing economies (Bruton, 2010; Mair \& Martí, 2006; Seelos \& Mair, 2005, 2007). However, social enterprises might face resource shortages because of their primary focus on a social mission (Wei-Skillern, Austin, Leonard, \& Stevenson, 2007). Furthermore, in a market characterized by financial crises, a social enterprise often has to compete for capital with traditional profit-oriented enterprises. In an enterprise's growing phase, this resource shortage can also affect the marketing function, which is one of the crucial processes for growth (Webster, 1992). Entrepreneurial marketing has been proposed as an innovative and less resource-intensive marketing method for small enterprises in their growing stages (Bjerke \& Hultman, 2002; Chaston, 2000; Gilmore, 2011).

Extensive discussions in the media and academia are taking place concerning the development of business solutions in resource-constrained environments (Lampel, Honig, \& Drori, 2011; Radjou, Prabhu, \& Ahuja, 2012; Rowlatt, 2013). Through a case study (Kannampuzha et al., 2014) of a collaboration between a Finnish university and an Indian social enterprise, the authors demonstrate how a social entrepreneur from a developing country addressed the resource constraints his venture faced during the development of its marketing strategy. The article describes the utilization of university faculty, students and entrepreneur mentors as resources in the social enterprise's branding and product

'This article is $($ Emerald Group Publishing and permission has been granted for this version to appear here (please insert the web address here). Emerald does not grant permission for this article to be further copied/distributed or hosted elsewhere without the express permission from Emerald Group Publishing Limited.'

DOI: http://dx.doi.org/10.1108/JRME-07-2015-0039 
development process. We used semi-structured interviews, student reports and field notes for our data collection. We present the concepts of network bricolage (Baker et al., 2003) and entrepreneurship education bricolage as two mechanisms for overcoming the resource shortages of a social entrepreneur. Shaw (2004) conducted a study on the marketing efforts of UK-based social enterprises with the objective of understanding whether an entrepreneurial element prevails in their marketing activities. The paper identified the role of networks in opportunity identification and resource acquisition (Shaw, 2004). In this paper, we explore this concept through an in-depth case study of the marketing strategy development process of a social enterprise in its initial growth stages.

In this context, the research question that we address is as follows:

RQ1. How does a social enterprise address resource constraints in its marketing strategy development during the start-up phase?

The paper begins with a literature review that examines the methods used to address resource constraints in social enterprises. Next, details on the methodology and the data collection are presented. The case description of collaboration between a social enterprise and an entrepreneurship education faculty follows this section. Following the data analysis of the interviews, we present the discussion of our model for bricolage entrepreneurial marketing. The study's implications and the limitations of the research are presented in the last section.

\section{Literature review}

\section{Resources and social enterprises}

'This article is $\odot$ Emerald Group Publishing and permission has been granted for this version to appear here (please insert the web address here). Emerald does not grant permission for this article to be further copied/distributed or hosted elsewhere without the express permission from Emerald Group Publishing Limited.'

DOI: http://dx.doi.org/10.1108/JRME-07-2015-0039 
Penrose (1956) proposed that firms are defined by the resources that they use to develop products and services. The growth and competitive advantage of a firm is determined by the resources that it possesses. Two firms that possess the same set of resources may develop different products and services using different combinations of the resources. In a new firm, entrepreneurs combine the existing resources to generate heterogeneous resources for new uses (Alvarez \& Busenitz, 2001). The resource advantage theory proposes that firms strive to achieve better performance through a comparative advantage in the resources that they possess (Hunt, 1997) . Resources that are valuable, rare, inimitable and non-substitutable are crucial for an organization, especially in addressing its marketing needs (Barney, 1991; Srivastava, Fahey, \& Christensen, 2001). The resource base of a new venture may consist of human, social, financial, physical, technological and organizational skills. For an enterprise in its nascent stages, it is always challenging to acquire the right resources. Resource constraints (Brush et al., 2001; Eggers, 2010) can hinder an organization's growth ambitions in the initial phase, and entrepreneurs engage in several different strategies to address this issue.

Social enterprises are ventures that focus on social value creation in a community in a self-sustainable manner (Austin, Stevenson, \& Wei-Skillern, 2006; Hockerts, 2010; Mair \& Martí, 2006; Santos, 2012; Zahra, Gedajlovic, Neubaum, \& Shulman, 2009). They propose to solve problems that private companies or the government are unable to solve (Defourny, 2001). Earnings generation has been identified as one of the key factors for the success of a social enterprise (Bloom \& Smith, 2010). However, a social enterprise's results are evaluated based on the

'This article is ( $)$ Emerald Group Publishing and permission has been granted for this version to appear here (please insert the web address here). Emerald does not grant permission for this article to be further copied/distributed or hosted elsewhere without the express permission from Emerald Group Publishing Limited.'

DOI: http://dx.doi.org/10.1108/JRME-07-2015-0039 
organization's social impact in addition to its economic gain (Dees, 2012, 1998), which can lead to decreased remuneration and compensation for personnel and therefore cause talented individuals to hesitate when considering working for a social enterprise. This scenario adds to the pressure on social entrepreneurs to use their resources wisely (Wei-Skillern et al., 2007). Weerawardena, Sullivan \& Mort (2006) proposed a multidimensional model for social entrepreneurship that is characterized by the dimensions of proactiveness, innovativeness and risk management within the constraints of the environment, sustainability and the social mission. Marketing has been identified as having the potential to contribute to the performance of enterprises in both the for-profit and the not-for-profit sectors (Ewing \& Napoli, 2005; Miles, Crispin, \& Kasouf, 2013). Marketing for social enterprises is a two-fold activity that comprises attracting both beneficiaries and funders. Social enterprises compete for donations and other types of support to sustain themselves (Dees, 1998). During the growth phase of a social enterprise, the entrepreneur might be required to approach different funding sources. As mentioned previously, because an inherent problem of resource shortage exists in social enterprises (Wei-Skillern et al., 2007), they need to apply unique methods to help them with their marketing strategies and tactics.

The resource constraints in a firm's growth phase force the firm to consider innovative ways to reach out to customers (Eggers, 2010; Stokes, 2000) and investors. Entrepreneurial marketing (Morris, Schindehutte, \& LaForge, 2002) is an innovative marketing method that has been described as the interface of marketing and entrepreneurship (Carson \& Gilmore, 2000; Gilmore, 2011; Jones, Suoranta, \& Rowley, 2013a) or as a marketing method for small- and medium-sized companies

'This article is () Emerald Group Publishing and permission has been granted for this version to appear here (please insert the web address here). Emerald does not grant permission for this article to be further copied/distributed or hosted elsewhere without the express permission from Emerald Group Publishing Limited.'

DOI: http://dx.doi.org/10.1108/JRME-07-2015-0039 
(Bjerke \& Hultman, 2002). Some entrepreneurial marketing tactics include word of mouth marketing (Keller, 2007), viral marketing (Hinz, Skiera, Barrot, \& Becker, 2011) and buzz marketing (Hausmann, 2012; Thomas, 2004). While analysing the marketing practices of successful entrepreneurs, Stokes (2000) found that they tend to serve a small base of customers and expand based on resource availability. Furthermore, they emphasized personal contact and word of mouth marketing for the transmission of information to customers, and they obtained market information informally through personal networks.

\section{Mechanisms to address resource constraints}

Resource leveraging is one way to approach the scarcity of resources in an organization (Hamel \& Prahalad, 1993). Any organization can attain a competitive advantage by transforming the resources that it possesses into a unique resource mix. However, a new venture may not possess the resources needed to follow several growth strategies. In this case, entrepreneurs will have to first gather the resources they need and then develop unique competencies for the organization. To obtain or attract the resources, entrepreneurs need to leverage their networks (Jones, Suoranta, \& Rowley, 2013b). Thus, entrepreneurs need to specify the resources that the venture needs and discover possible suppliers of these resources (Brush et al., 2001). Resource leveraging is the usage of external resources when an entrepreneur in a firm does not possess the required resources for the firm's growth. When employing resource leveraging, an entrepreneur actively seeks resources that are not readily available (Brush et al., 2001; Wilson \& Appiah-Kubi, 2002) .

'This article is $@$ Emerald Group Publishing and permission has been granted for this version to appear here (please insert the web address here). Emerald does not grant permission for this article to be further copied/distributed or hosted elsewhere without the express permission from Emerald Group Publishing Limited.'

DOI: http://dx.doi.org/10.1108/JRME-07-2015-0039 
Lampel, Honig \& Drori $(2011,2014)$ defined ingenuity as one mechanism that can be used to address constraints. They defined it as the ability to create innovative solutions within structural constraints using limited resources and imaginative problem solving. The constraints in this context could be imposed by existing structures, a shortage of time or the inadequacy of resources. Resource constraints force the actors involved to be creative by performing constraint-shattering activities. Constraint shattering involves challenging the existing situation and performing creative operations to address the constraint.

\section{Bricolage as an entrepreneurial mechanism}

Bricolage is one form of constraint-shattering activity that entrepreneurs and the employees in an organization implement (Lombardo \& Kvalshaugen, 2014). In the start-up phase, many entrepreneurs who have insufficient resources manage to utilize the existing resources at hand in new combinations. This approach has been called entrepreneurial bricolage (Baker \& Nelson, 2005). In contrast to resource leveraging, where the entrepreneur searches for external resources, in bricolage the entrepreneur relies on the resources that he already possesses. Levi Strauss (1966) identified the concept of bricolage based on his study on how individuals interact with the environments in which they live. Baker \& Nelson (2005) used the concept of bricolage to explain the process that entrepreneurs follow in the event of a resource shortage. While suffering from resource shortages, the entrepreneurs examined in the study were able to provide unique services by recombining what they could procure around them. Thus, bricolage is defined as the process of creating something out of nothing in resource-constrained environments. The authors

'This article is ( $)$ Emerald Group Publishing and permission has been granted for this version to appear here (please insert the web address here). Emerald does not grant permission for this article to be further copied/distributed or hosted elsewhere without the express permission from Emerald Group Publishing Limited.'

DOI: http://dx.doi.org/10.1108/JRME-07-2015-0039 
proposed that bricolage consists of three main characteristics: resources at hand, a recombination of the resources at hand for new purposes and making do. Effectuation (Sarasvathy, 2001) is another approach where an entrepreneur builds a company based on the resources that he possesses. Both effectuation and bricolage start with the resources at hand. However, bricolage can be applied to achieve both an unspecified goal with the existing means (effectuation) and a predefined goal using the existing resources (causation) (Baker et al., 2003).

A bricoleur gathers resources with the aim of there being possible uses for said resources in the future. An entrepreneur could, for example, use already existing professional contacts to obtain skills to develop the company by gathering resources that are non-expensive or deemed worthless by others. Such resources could be physical materials, skills or ideas that are collected for an unforeseen project in the future. A bricoleur experiments with different amalgamations of existing resources to see whether they provide a solution to the issue at hand. Although Schumpeter (1934) and Penrose (1956) proposed that firms recombine existing resources in new combinations, they do not describe how firms perform such recombinations. In bricolage, individuals continuously question their constraints by experimenting with different solutions and managing the results. The making do aspect emphasizes dynamic involvement over exhaustive thinking and planning. Making do does not imply that a solution is highly imperfect; rather it is a construct that forces an individual to act instead of contemplating whether the existing resources will lead to an optimal result (Baker \& Nelson, 2005; Bjerke \& Hultman, 2013). The bricolage concept has been used to explain processes in technology entrepreneurship (Garud

'This article is () Emerald Group Publishing and permission has been granted for this version to appear here (please insert the web address here). Emerald does not grant permission for this article to be further copied/distributed or hosted elsewhere without the express permission from Emerald Group Publishing Limited.'

DOI: http://dx.doi.org/10.1108/JRME-07-2015-0039 
\& Karnøe, 2003) and organizational strategy (Phillips \& Tracey, 2007), social bricolage in social enterprises (Di Domenico, Haugh, \& Tracey, 2010), and intrapreneurship in multinational corporations (Halme, Lindeman, \& Linna, 2012). Social entrepreneurs are considered experts in mobilizing resources in a manner similar to enterprising bricoleurs (Desa, 2012).

Bjerke \& Hultman (2013) differentiated between a broad view and a narrow view of entrepreneurship. They proposed that the broad view of entrepreneurship considers it as a social phenomenon that is focused on satisfying the demands and needs of society. In contrast, the narrow view of entrepreneurship perceives it as an economic phenomenon. Entrepreneurs in this category develop new firms and processes rationally. In the broad view of entrepreneurship, many new start-ups begin their operations naturally and utilize bricolage as a development method. Bjerke \& Hultman (2013) defined bricolage as a way of starting something new by involving actors in a process where genuinely new combinations come up, and existing resources are transformed for old or new purposes. While engineers look at the problem rationally and create rational start-ups, a bricoleur will look at a problem naturally and construct a natural start-up. Bricolage attempts to understand how businesses start by looking at entrepreneurs as agents of social construction. In that context, marketing could be defined as the intermittent and flexible utilization of the means at hand following effectuation or bricolage. In this broad view, the solutions to a customer's problems are co-created with them. Bricoleurs tend to apply networks as a genuine method of co-creation. In a natural start-up, the entrepreneur who acts as a bricoleur will generally follow a broad view and use entrepreneurial marketing

'This article is (c) Emerald Group Publishing and permission has been granted for this version to appear here (please insert the web address here). Emerald does not grant permission for this article to be further copied/distributed or hosted elsewhere without the express permission from Emerald Group Publishing Limited.'

DOI: http://dx.doi.org/10.1108/JRME-07-2015-0039 
techniques (Bjerke \& Hultman, 2013; Hills \& Hultman, 2006). In this paper, we develop this concept using a demonstrative case study of an Indian social enterprise using the resources that it already possesses. We address the question of resource usage in an early-stage social enterprise using a case of marketing strategy development in collaboration with a university. The summary of the literature review is presented in the Table I.

\begin{tabular}{lll}
\hline Mechanism & Literature & Explanation \\
\hline Ingenuity & (Lampel et al., 2011, 2014) & $\begin{array}{l}\text { Entrepreneur uses creative and } \\
\text { imaginative problem solving in resource } \\
\text { constrained environments. }\end{array}$ \\
$\begin{array}{l}\text { Resource } \\
\text { leveraging }\end{array}$ & $\begin{array}{l}\text { (Brush et al., 2001; Hamel \& } \\
\text { Prahalad, 1993; Wilson \& } \\
\text { Appiah-Kubi, 2002) }\end{array}$ & $\begin{array}{l}\text { Seeking resources not owned externally } \\
\text { through a previously unknown contact. }\end{array}$ \\
$\begin{array}{ll}\text { Effectuation } \\
\text { (Sarasvathy, 2001) }\end{array}$ & $\begin{array}{l}\text { Entrepreneur in an uncertain environment } \\
\text { uses existing resources to develop a new } \\
\text { venture. }\end{array}$ \\
$\begin{array}{l}\text { Entrepreneurial } \\
\text { bricolage }\end{array}$ & $\begin{array}{l}\text { (Baker \& Nelson, 2005; Lévi- } \\
\text { Strauss, 1966) }\end{array}$ & $\begin{array}{l}\text { Recombining existing resources at hand } \\
\text { to develop "good enough" solutions to } \\
\text { problems. }\end{array}$ \\
\hline
\end{tabular}

Table I. Mechanisms to address resource constraints by entrepreneurs

\section{Methodology}

When a researcher is exploring the 'how' of an evolving phenomenon in which he or she has little control, a case study can be extremely useful (Eisenhardt \& Graebner, 2007; Eisenhardt, 1989; Yin, 2009). The authors used an in-depth case study as the methodology in this study through a revelatory case that provides insightful knowledge of the experience. The data used were collected over a period of two 'This article is @ Emerald Group Publishing and permission has been granted for this version to appear here (please insert the web address here). Emerald does not grant permission for this article to be further copied/distributed or hosted elsewhere without the express permission from Emerald Group Publishing Limited.'

DOI: http://dx.doi.org/10.1108/JRME-07-2015-0039 
years. The background information about the case was collected during a field trip to India through open-ended interviews with the founder, management team and employees of a social enterprise. Updated information about the social enterprise was continuously collected via emails from researchers based in India and constant interaction with the founder of the enterprise throughout the period of the study. The primary data for this article include semi-structured interviews with students involved in the development of the social enterprise, focus group interviews with the students and interviews with the students' mentors regarding the design of the marketing strategy. In addition, a few interviews and discussions were conducted with the entrepreneur. For the interviews, open-ended questions were used that focused on the social enterprise's marketing efforts. The interviews varied in length from $30 \mathrm{~min}$ to $1.5 \mathrm{~h}$. The secondary data for the paper include email discussions with the social enterprise's team members, an online discussion forum with the students who worked on the marketing project and marketing strategy reports developed by the students. In total, we had 40 informants. The details of the data sources for the paper are provided in Table II. A thematic analysis was performed on the data, and coding was used for the analysis of the transcripts (Auerbach \& Silverstein, 2003). In the interview transcripts, we looked for themes related to the process of how resources were utilized in the development of the marketing strategy.

$\begin{array}{llll}\text { Project involved } & \text { Role } & \begin{array}{l}\text { No. of } \\ \text { informants }\end{array} & \text { Data sources } \\ \begin{array}{l}\text { Indian health venture - } \\ \text { GVL collaboration }\end{array} & \text { Entrepreneur, GVL mentors } & 5 & \begin{array}{l}\text { Interviews, } \\ \text { informal discussions }\end{array}\end{array}$

'This article is () Emerald Group Publishing and permission has been granted for this version to appear here (please insert the web address here). Emerald does not grant permission for this article to be further copied/distributed or hosted elsewhere without the express permission from Emerald Group Publishing Limited.'

DOI: http://dx.doi.org/10.1108/JRME-07-2015-0039 
Market strategy

development (January - Students

June 2010)

Motherhood package

development (November Students

2010 - March 2011)
3

$12 \quad \begin{aligned} & \text { Panel discussion, } \\ & \text { interviews, student }\end{aligned}$ project reports

Table II. Data sources for this paper

\section{Description of the case}

The Indian rural health venture was started by a professor at the Indian Institute of Technology Kharagpur (IIT, Kgp) to address the issue of the inaccessibility of health care facilities in non-urban parts of India. He personally funded the venture to select and train rural entrepreneurs at the entrepreneurship centre of IIT Kgp. The trained entrepreneurs aimed to provide affordable medical diagnostic services to local people in health centres with remote connections to a hospital with high-end facilities. Services such as blood sugar measurement and blood pressure measurement are provided at a kiosk where the patient is charged a small amount, less than one dollar. A high number of individuals visiting the kiosk would generate good income for the local entrepreneur while providing affordable health services in the non-urban area. Although the founder hoped to expand the venture to non-urban areas in all regions of India, it experienced resource shortages. To develop strategies for marketing and the growth of the business, the Indian professor approached Global Venture Lab (GVL) Finland. The GVL is a network of universities in different countries that are interested in developing a global university-based business creation platform. The Indian professor was one of the founding members of the network together with a

'This article is $@$ Emerald Group Publishing and permission has been granted for this version to appear here (please insert the web address here). Emerald does not grant permission for this article to be further copied/distributed or hosted elsewhere without the express permission from Emerald Group Publishing Limited.'

DOI: http://dx.doi.org/10.1108/JRME-07-2015-0039 
professor at the business school at the University of Jyvaskyla, Finland. The Indian professor also taught courses as a visiting faculty member. These existing professional relationships with the faculty at the University of Jyvaskyla allowed the Indian professor to reach out to the faculty to address the issue of resource constraints.

\section{Health venture branding strategy development}

GVL Finland faculty offered students the opportunity to learn the concepts of entrepreneurship, business and management within the context of practical cases and real companies. The students had to solve a business problem for a company by applying the theories they learned in their classes. The Indian professor presented his venture to the students in December 2009 at the University of Jyvaskyla. In the spring semester of 2010, students enrolled in the Project Management course were assigned to the case of the Indian rural health venture. The students were expected to manage the project as a group and make progress in solving the issues facing the company. The students are constantly reviewed in meetings with mentors from the GVL who are individuals with previous entrepreneurship and business experience. When the semester ends, the students produce a report that details their proposed solution for the company.

From January to June 2010, three student groups worked on projects for the Indian rural health venture. The students had Finnish, German and Italian nationalities and were majoring in subjects varying from linguistics to physics. A brainstorming workshop event conducted by GVL mentors and the students identified three projects for development: a logo, the creation of a support community in

'This article is () Emerald Group Publishing and permission has been granted for this version to appear here (please insert the web address here). Emerald does not grant permission for this article to be further copied/distributed or hosted elsewhere without the express permission from Emerald Group Publishing Limited.'

DOI: http://dx.doi.org/10.1108/JRME-07-2015-0039 
Finland and story development for potential donors to the Indian health venture. The students involved in the projects formed an online discussion group and communicated with researchers involved in the Indian rural health venture through conference calls. They were mentored by three GVL Finland faculty members who called feedback meetings during the course of the project. To develop the logo, the students researched Indian culture, the Indian health care system and successful Indian brands. They analysed Indian advertising campaigns that appealed to rural Indians as well as an international audience. Based on their research and the names and pictures currently utilized for the venture, the students developed three suggestions for a name and logo that were professionalized by a local advertising agency. Additionally, the students developed a future scenario story describing how donor involvement could positively impact the Indian rural health venture. The third assignment was to develop a community to support the venture. To reach out to the younger student population, the students developed a Facebook page for the venture that could be updated frequently with the venture's new developments. Other proposals developed by the students included an online student volunteer database, a pitch to reach out to Finnish public figures, micro-financing to help kick start new kiosks and an online shop for rural Indian art products that could be sold at premium prices to help finance the kiosk venture. The students also developed an action plan on how to proceed with the brand strategy execution to attract global interest for the venture. The marketing efforts of the students and the GVL mentors produced its first result when a Finnish firm provided the first donation for a health kiosk in December

'This article is () Emerald Group Publishing and permission has been granted for this version to appear here (please insert the web address here). Emerald does not grant permission for this article to be further copied/distributed or hosted elsewhere without the express permission from Emerald Group Publishing Limited.'

DOI: http://dx.doi.org/10.1108/JRME-07-2015-0039 
2010. The various events during the branding strategy development are presented in Table III.

\section{Time Period Description}

December 2009 Introduction to the Indian health venture case by entrepreneur.

Logo development, creation of a support community in Finland, January 2010 and the creation of a story for donors about the Indian rural health venture are identified as the problems for students to work on.

February 2010

Basic study of the Indian rural health venture and brainstorming by student groups.

Discussion with Indian team and feedback on the students' firs

March 2010 ideas; presentation of Indian rural health venture to local organizations in central Finland.

April $2010 \quad$ Presentation of improved logo ideas to marketing company in Finland; pro bono work on improving the logos by the company.

May 2010 Development of Facebook community.

June $2010 \quad$ Final report with suggestions from students.

August 2010 Feedback on the final report of the students.

December 2010

First donation from a Finnish organization to the Indian rural health venture.

Table III. Key events in the Indian social enterprise marketing strategy development, spring 2010

\section{Motherhood package development}

During a research trip by GVL Finland faculty to India in August 2010, the student reports on the marketing strategy with logo suggestions and future scenario stories for the Indian rural health venture were presented to the venture's management team at IIT Kgp, and feedback was collected. During the trip, it was determined that to scale and expand, the health venture needed to increase trust among the local communities. Because mothers are often responsible for the health care of their families, mothers and children were identified as value customers. It was agreed that an idea similar to the motherhood package provided by the Finnish social

'This article is () Emerald Group Publishing and permission has been granted for this version to appear here (please insert the web address here). Emerald does not grant permission for this article to be further copied/distributed or hosted elsewhere without the express permission from Emerald Group Publishing Limited.'

DOI: http://dx.doi.org/10.1108/JRME-07-2015-0039 
security system (Lee, 2013) would be appropriate for integration into the Indian rural health venture. In the late Autumn of 2010 , students enrolled in the next project management course offered by GVL Finland faculty were introduced to the project to develop the Indian Motherhood Package, which was to be sold through the Indian rural health venture. The GVL mentors collaborated with three student groups and helped them design and develop their ideas for the motherhood package. The students presented their work in three phases with constant feedback from the GVL mentors and the managers of the Indian venture. In the first phase of the project delivery, the students were expected to present the project idea proposal and a timeline for the next two phases. Based on feedback on their ideas from the presentation of the first phase and individual discussions with the mentors, the students were expected to improve their ideas. After improving their ideas based on the feedback, the students submitted a mid-level report and a list of milestones that they achieved in the second phase. In the third phase, the students presented their main ideas and achievements and a 5-min elevator pitch of their idea. The first group of students focused on developing a motherhood programme with services in addition to the products in the package. The second group of students established contacts with Finnish organizations who have worked in the field of healthcare in the rural regions of developing countries. The third group of students focused on the idea of developing sample packages with the help of the Finnish social security system to test the market in India. The various events during the motherhood package development are presented in Table IV.

'This article is (c) Emerald Group Publishing and permission has been granted for this version to appear here (please insert the web address here). Emerald does not grant permission for this article to be further copied/distributed or hosted elsewhere without the express permission from Emerald Group Publishing Limited.'

DOI: http://dx.doi.org/10.1108/JRME-07-2015-0039 


\begin{tabular}{ll}
\hline Time Period & Description \\
\hline August 2010 & Motherhood package identified as next project. \\
December 2010 & $\begin{array}{l}\text { Theoretical classes in project management course. } \\
\text { Three student groups signed up to develop the Indian motherhood } \\
\text { package. }\end{array}$ \\
January 2011 & First phase report for the project; feedback provided. \\
February 2011 2011 & Second phase report of the project; feedback provided by mentors. \\
March 2011 & Final presentation. \\
\hline
\end{tabular}

Table IV. Key events in the mother package design project, spring 2011

\section{Findings}

Based on the thematic analysis, we find the following themes in the process.

\section{Resource constraints}

The project had resource constraints from the perspectives of both the social entrepreneur and the students who were involved in the social enterprise's marketing process. Below, we present the resource constraints that we observed in the process.

Lack of money and business experience. From the perspective of the

entrepreneur, the venture lacked money and business experience. The entrepreneur lacked money to hire an actual marketing firm for the branding of the social enterprise. The entrepreneur mentioned the following in the interview:

'We had resources, but not money' [...] So we [...] don't have [...] people with real money and real resources and own private capital (Entrepreneur).

The rural health venture had students from IIT Kgp who enrolled for the program at the entrepreneurship faculty. The students had strong educational backgrounds in engineering but limited knowledge of business and marketing theories. In the entrepreneur's own words,

'I wanted to have engineers in IIT to find out how to use their knowledge for business.' (Entrepreneur).

'This article is $\odot$ Emerald Group Publishing and permission has been granted for this version to appear here (please insert the web address here). Emerald does not grant permission for this article to be further copied/distributed or hosted elsewhere without the express permission from Emerald Group Publishing Limited.'

DOI: http://dx.doi.org/10.1108/JRME-07-2015-0039 
Lack of information, time and practical experience. From the perspective of the students and the GVL Finland faculty who worked on the projects for the Indian rural health venture, the main resource constraints were information and time. The first problem was posed by the fact that European students were involved in the marketing strategy development of an Indian health-care venture. The venture was still in its initial stages, and it was difficult to obtain up-to-date information. The students had a great deal of difficulty understanding the local Indian culture, which was foreign to them, while developing the marketing strategy. The students felt that the development of a marketing strategy would have been easier if the organization operated in a country that was familiar to them.

As a student mentioned regarding the difficulties encountered in the project:

Being so distant from India. Kind of a difficulty. You don't have the first-hand knowledge of the culture. And maybe, if it was in Russia or Finland or Sweden, you could go there. And it would be easier to share the idea with others. So, the first-hand experience would be important in my opinion. (Student J).

We would have wanted to have a connection to the health venture in India so that they could have verified our idea. We could have had more feedback from them at this point so that we could develop our idea further (Student T).

The solutions for the marketing problems had to be developed within the semester, which was limited time. In addition, the students were troubled by the fact that the entrepreneur himself was not present to provide direct feedback on the students' ideas and proposals:

I was a bit sceptical because the founders are not here, and we don't have communication with them [...]. Of course, I would have wanted to see the founders and actually talk to them, ask their opinion and maybe do some surveys among the customers. I already talked about how we don't have direct access to the founding team [...] That's a real problem for me at least (Student $P$ ).

'This article is () Emerald Group Publishing and permission has been granted for this version to appear here (please insert the web address here). Emerald does not grant permission for this article to be further copied/distributed or hosted elsewhere without the express permission from Emerald Group Publishing Limited.'

DOI: http://dx.doi.org/10.1108/JRME-07-2015-0039 
I knew that it might be a little difficult within this time, and what can you do for the tech side in 4 months? (Student J).

But, really it was a huge challenge to design the maternity package for India. None of us have been to India, and we don't know about the conditions there, and we worked a lot to get to know how things are there, and we did our best (Student $A$ ).

Finally, the students faced several obstacles in their project because of their lack of experience. In the Spring of 2011, the students felt that they could not develop the ideal motherhood package because they did not know about motherhood and healthcare conditions in India.

We are students [...] We are not professionals. We don't know health care.

We feel that we cannot advise them because we are not mothers. I don't have babies (Student A).

\section{Resources at hand}

Existing networks as a resource. The entrepreneur in this case used his personal networks for the development of the marketing strategy. Because the social enterprise was based in an Indian university, it lacked money to hire a marketing agency. At first, he utilized his own funds to start the venture:

And I was at that time using my own personal resources, some amount of money like 10,000 euros (Entrepreneur).

In addition, the professor utilized the students and staff at the entrepreneurship centre, of which he was a part, to develop the Indian rural health venture.

Me and my staff at IIT started an education venture where we were trying to educate rural kids (Entrepreneur).

To develop the marketing strategy, he approached his existing network with the GVL Finland faculty. In reaching out to his university network in Finland, the founding entrepreneur followed an approach of utilizing the skills he could access among his personal networks.

'This article is $\odot$ Emerald Group Publishing and permission has been granted for this version to appear here (please insert the web address here). Emerald does not grant permission for this article to be further copied/distributed or hosted elsewhere without the express permission from Emerald Group Publishing Limited.'

DOI: http://dx.doi.org/10.1108/JRME-07-2015-0039 
The GVL Finland faculty and IIT Kgp could actually contribute to the prosperity of the business $[\ldots]$ as far as possible.

I met the Finnish professor through a common friend of ours in Berkeley [...] I was visiting UC Berkeley in 2006, and when discussing [...] new ways to come up with opportunities for growth, a friend introduced me to the UC Berkeley professor, and then he said, you know what? [...] There is a very interesting bunch of guys in Finland trying to do a venture exploration, and we are going to call it Global Venture Lab. Would you like to join us? You can go and talk about your vision there. And he gave me the phone number of the Finnish professor, and I called him, and [...] It was great (Entrepreneur).

University students as a resource. The entire process was conducted by utilizing the students at the university as a resource. For the development of the venture, the entrepreneur reached out to the network of universities that collaborated with his own university. The technical solutions for the Indian health centres were developed at IIT Kgp. Students at the GVL Finland and UC Berkeley were involved in the venture's business development. The venture used the easily available resources of the students in the GVL network to help it develop a marketing strategy, and while developing the strategy, the students were aided by mentors who were experienced in marketing. As stated by the entrepreneur;

So IIT students on the technology and deployment, Finland folks on the blending and Berkeley folks on the costs and revenue plan (Entrepreneur).

The students in Finland looked at the social enterprise from a European point of view. They viewed it as a resource that had potential for the Indian rural health venture. One student noted that their freedom could be a beneficial resource:

It's a kind of a benefit anyways because it's such a free environment. Easy to access the project group. Easy to get people in (Student J).

Faculty mentors as a resource. GVL Finland had members with business and entrepreneurship experience who acted as mentors for the student groups. They had previously founded firms and developed growth strategies for start-ups. They helped

'This article is () Emerald Group Publishing and permission has been granted for this version to appear here (please insert the web address here). Emerald does not grant permission for this article to be further copied/distributed or hosted elsewhere without the express permission from Emerald Group Publishing Limited.'

DOI: http://dx.doi.org/10.1108/JRME-07-2015-0039 
the students during the market strategy development process, and their experience

was a resource that all of the students appreciated.

I guess he [the faculty mentor] gave us straight contacts with companies [...] names, which might not have been easy to get from a person who doesn't know the business world (Student M).

\section{Recombining resources at hand for new purposes}

The collaboration processes involved the usage of university resources in a unique manner. The lack of business acumen among the engineering students at IIT was addressed by utilizing students at a business school in Finland. The abilities that the students from different universities possessed were combined to produce a package that could be used by the Indian rural health venture. Students, the experienced mentors and the entrepreneurs together created a new method of pedagogy. Through this process, the university resources were recombined in novel ways to aid in the development of a new social enterprise.

Students driving enterprises, I have always discussed that with my other colleagues in Finland. Students are very potent force, but they are unorganized. And then they are not formal. And I am a formal social firm that needs your help (Entrepreneur).

GVL can be a good, healthy foundation, professors and practitioners and venture capitalists and evangelists trying to come together using the university as a platform for bringing IPRs together, the university as a platform to bring people together, the university as a platform to combine research and academics and practitioners into monetizable solutions for problems worth solving. That's the concept in my mind (Entrepreneur).

The group of students that worked on the branding and marketing strategy development consisted of Finnish students as well as international exchange students. The students' majors included languages, natural sciences and business. The groups consisted of students from varied academic backgrounds such as physics, music, sociology and economics and students from three different

'This article is $($ Emerald Group Publishing and permission has been granted for this version to appear here (please insert the web address here). Emerald does not grant permission for this article to be further copied/distributed or hosted elsewhere without the express permission from Emerald Group Publishing Limited.'

DOI: http://dx.doi.org/10.1108/JRME-07-2015-0039 
nationalities, which led to varied perspectives and produced good results. As stated by the students who worked on the project in the spring of 2010 :

International team, that was great. And everyone has their own idea and background, and of course, an international team from different majors, technical, ICT (Information and Communication Technology) and biz econ, and we had only 3 or 4 Finns (3) and almost the same amount of international people and for this kind of international project [...] (Student J).

We had different points of view. I didn't think it was a problem. People lacking business knowhow for instance, the physics majors, I never got the impression that they wouldn't get our points of view. I think it was a good thing because we had more assets which were multifaceted (Student $P$ ).

I like to work with multiple nationalities as I have done so before, and it gives some perspective to the whole process and some new ideas (Student $P$ ).

During the marketing strategy development process, one resource that was utilized in solving problems was existing knowledge from Finnish society. One of the ideas that recurred concerned the Finnish maternity clinics and hospitals offering free treatment for pregnant mothers and infants. Another idea was that of the Martha organization which is a Finnish home economics organization established in 1899 to provide education to women and to promote their well-being and quality of life at home. Students identified that this model could be utilized in the rural Indian context.

We could perhaps benefit from the knowledge and the Finnish history in terms of building the pre-natal training in India which would be something like maternity clinic in Finland [...] There could be some connections like that (Student $K$,).

We can give advice which the Indians might not even think about. For example, we have this Martha organization which have had a huge impact on the Finnish history, and we could do something similar in India (Student $A$ ).

\section{Making Do}

The entrepreneur was trying to make things work, but he sometimes had to make adjustments using non-ideal solutions. He mentioned how he used the money that

'This article is ( $)$ Emerald Group Publishing and permission has been granted for this version to appear here (please insert the web address here). Emerald does not grant permission for this article to be further copied/distributed or hosted elsewhere without the express permission from Emerald Group Publishing Limited.'

DOI: http://dx.doi.org/10.1108/JRME-07-2015-0039 
the social enterprise obtained from a business plan competition to promote the maternity package. Because he lacked money, he sustained the venture using the resources that he could obtain.

I pumped that money into the kiosk as well, and then I started going to the next level trying to make the interior better and the exterior better, trying to bring in more pictures of a mother and child(Entrepreneur).

The students had to believe that the practical issues were going to be taken care of later. Furthermore, some of the organizations they contacted did not respond because they considered the venture to only be a student project, but the students tried to produce a result that could be usable. They tried to develop solutions in the limited time available to them of one semester.

Get out of the building and do something concrete for the customers and check whether it works or not and stuff like that [...] But I think in this case, it was like creating the initial idea that we could [...] and actually to test out the business model and get out of the building [... jbut it was as good as it can get for this state that we are in (Student P).

I am used to the idea that you have to have the perfect idea and the perfect image about something before you go and talk about it ... But now what was done was that you had to be willing to be more creative and just like hands-on the issue and keep contacting the companies (Student E).

\section{Discussion}

Based on our data analysis, the bricolage process in the development of a marketing strategy for the Indian rural health venture is summarized in Table V. The constraints of lack of money, business experience and cultural knowledge forced the individuals to recombine the resources they possessed to produce applicable solutions.

\begin{tabular}{llll}
\hline $\begin{array}{l}\text { Resource } \\
\text { constraints }\end{array}$ & $\begin{array}{l}\text { Resources at } \\
\text { hand }\end{array}$ & $\begin{array}{l}\text { Recombination of } \\
\text { resources }\end{array}$ & Making do \\
\hline Entrepreneur's & $\begin{array}{l}\text { University } \\
\text { students and } \\
\text { staff }\end{array}$ & $\begin{array}{l}\text { Reusability of solutions } \\
\text { between Finland/India }\end{array}$ & $\begin{array}{l}\text { Solutions developed without } \\
\text { spending money }\end{array}$ \\
\hline lack of money & &
\end{tabular}

'This article is (c) Emerald Group Publishing and permission has been granted for this version to appear here (please insert the web address here). Emerald does not grant permission for this article to be further copied/distributed or hosted elsewhere without the express permission from Emerald Group Publishing Limited.'

DOI: http://dx.doi.org/10.1108/JRME-07-2015-0039 
Students' lack of information

Lack of business experience for technical students in India

Lack of Indian experience for students in Finland
Collaboration between Indian entrepreneur \& researchers

Student mentors with business experience

Diverse educational background and nationalities of students in project groups
New perspectives and solutions to the problem using own experience and knowledge

Reusing university resources and networks to create a new method of pedagogy

Utilizing experiences from students' native country in a novel way
Ability to develop a practical \& optimal solution with limited information

Solutions produced in short time and with limited information

Making up for the lack of knowledge of local culture using own experiences

Table V. Bricolage in the marketing of a social enterprise

The case of collaboration discussed above demonstrates the process of bricolage in the marketing of a social enterprise. Figure I represents the concept of 'bricolage in entrepreneurial marketing' as comprising network bricolage and entrepreneurship education bricolage. In our study we observed the strategies used for marketing by the entrepreneur. We identified two separate processes of bricolage in the marketing strategy development. One was network bricolage through which the entrepreneur accessed resources. The second process of bricolage was the entrepreneurship education bricolage which occurred by using students as a resource to develop the marketing strategy. Both of the bricolage processes are explained in detail below.

\section{Bricolage in entrepreneurial marketing}

Resources at hand

Recombining resources at hand Making do

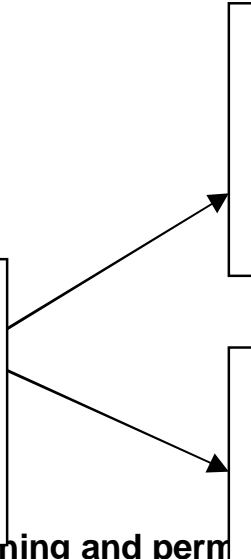

to appear here (please insert the web address here).

Bricolage in entrepreneurship education

Students as a resource for marketing strategy this article to be further copied/distributed or hosted elsewhere without the express permission from Emerald Group Publishing Limited.'

DOI: http://dx.doi.org/10.1108/JRME-07-2015-0039 
Figure 1. Bricolage entrepreneurial marketing

\section{Network bricolage}

When faced with the constraints of a lack of money and a lack of business experience in his team, the entrepreneur of the Indian health venture adopted the constraint-shattering mechanism of utilizing his available resources through his existing professional and personal networks. The role of networks is considered crucial for marketing in social enterprises (Shaw, 2004). We identified network bricolage in the process of the collaboration between the Indian social venture and the GVL Finland. Network bricolage is a type of bricolage in which entrepreneurs utilize their existing personal and professional networks as a resource at hand. Networking has always been crucial for firms in their initial period to help fuel their growth. Researchers have demonstrated that entrepreneurs utilize network resources heavily (Aldrich \& Zimmer, 1986; Birley, 1985; Jones et al., 2013b; Mattson, 1997; Ostgaard \& Birley, 1996; Vasilchenko \& Morrish, 2011). Whereas networking and resource leveraging implies that the founders of an organization pursue resources from previously unknown people, network bricolage involves already known contacts of the entrepreneur (Baker et al., 2003).

This finding has a practical implication for entrepreneurs in their initial stage of developing their firm. An entrepreneur needs to combine the existing resources that he possesses in a unique way to creatively solve problems. The entrepreneur can

'This article is (c) Emerald Group Publishing and permission has been granted for this version to appear here (please insert the web address here). Emerald does not grant permission for this article to be further copied/distributed or hosted elsewhere without the express permission from Emerald Group Publishing Limited.'

DOI: http://dx.doi.org/10.1108/JRME-07-2015-0039 
look at his existing network contacts and reuse them in an innovative way when there are resource constraints.

\section{Entrepreneurship education bricolage}

Another type of bricolage that we observed was what we call entrepreneurship education bricolage, which refers to the process that the students underwent while trying to develop solutions for the problems faced by the Indian health venture. When faced with obstacles, they proceeded with the knowledge that they had. Co-creation in marketing is a term that is normally used to refer to activities that an entrepreneur undertakes to develop new products in collaboration with customers and end users (Prahalad \& Ramaswamy, 2004). In this case study, we observed co-creation with students as a mechanism to address a resource shortage. Teaching is proposed to be a process that involves bricolage (Hatton, 1988). We identified a bricolage process in entrepreneurship education where previously unrecognized resources were recombined to aid the development process of a social enterprise. The combination of students, faculty researchers, business mentors and university resources of IIT Kgp and GVL Finland were utilized as an ingenuity mechanism to develop creative solutions to address the marketing resource shortage.

Students are an underused resource that entrepreneurs could utilize in novel ways. There is general interest among students in volunteering to work for social enterprises. Entrepreneurship educators should develop their pedagogical process to address these two synergies. Students could design value-adding products and services for an enterprise using social media and modern technologies. From the research case that we presented, it is evident that social enterprises and

'This article is $\odot$ Emerald Group Publishing and permission has been granted for this version to appear here (please insert the web address here). Emerald does not grant permission for this article to be further copied/distributed or hosted elsewhere without the express permission from Emerald Group Publishing Limited.'

DOI: http://dx.doi.org/10.1108/JRME-07-2015-0039 
entrepreneurs can utilize the enthusiasm of students to their advantage during their marketing efforts. However, students are inexperienced compared with business consultants, and they require some level of guidance from experienced personnel. Furthermore, innovative ways to develop marketing strategies and collect feedback from the entrepreneur need to be adopted, as students do not always have direct access to the end customer.

\section{Limitations and conclusions}

This paper explored the marketing strategy development process of a social enterprise. The process of entrepreneurial bricolage was identified in the context of analysing the efforts of a social enterprise that was developed through a university's venture creation platform. The case presented a possible example of utilizing students as resources who can help a social enterprise develop its marketing strategy during its growth phase. Social entrepreneurship is proposed to advance macro-marketing (Miles et al., 2013). In this paper, we responded to the call by Bjerk \& Hultman (2013) to examine the broad view of entrepreneurship and its implications on marketing. We identified bricolage in the marketing strategy development process of an early-stage social enterprise. In addition, we observed the role of networks in marketing a social entrepreneurship enterprise (Shaw, 2004), and we observed the process of network bricolage. However, the research has some limitations.

First, the research was conducted on a single social enterprise based in India, which limits the generalizability of the research to all social enterprises. Future research could examine how ingenuity and specifically bricolage is used in marketing and other processes in multiple social enterprises. Second, the authors focused on

'This article is () Emerald Group Publishing and permission has been granted for this version to appear here (please insert the web address here). Emerald does not grant permission for this article to be further copied/distributed or hosted elsewhere without the express permission from Emerald Group Publishing Limited.'

DOI: http://dx.doi.org/10.1108/JRME-07-2015-0039 
exploring the marketing strategy development of a social enterprise in collaboration with universities. The field of marketing for a social enterprise has been explored on a small scale in the existing academic literature (Shaw, 2004), which provides a great opportunity to researchers in this field to analyse the marketing strategy development of various social enterprises. One interesting area to examine would be the usage of social media in funding a social enterprise's search and marketing efforts.

\section{References}

Aldrich, H., \& Zimmer, C. (1986). Entrepreneurship Through Social Networks. In The Art and Science of Entrepreneurship (pp. 3-23). http://doi.org/10.2139/ssrn.1497761

Alvarez, S. A., \& Busenitz, L. W. (2001). The entrepreneurship of resource-based theory. Journal of Management, 27(6), 755-775. http://doi.org/10.1177/014920630102700609

Auerbach, C., \& Silverstein, L. B. (2003). Qualitative Data: An Introduction to Coding and Analysis (Qualitative Studies in Psychology) (p. 202). NYU Press. Retrieved from http://www.amazon.com/Qualitative-Data-Introduction-AnalysisPsychology/dp/0814706959

Austin, J., Stevenson, H., \& Wei-Skillern, J. (2006). Social and commercial entrepreneurship: Same, different, or both? Entrepreneurship: Theory and Practice, 30(1), 1-22. http://doi.org/10.1111/j.1540-6520.2006.00107.x

Baker, T., Miner, A. S., \& Eesley, D. T. (2003). Improvising firms: Bricolage, account giving and improvisational competencies in the founding process. Research Policy, 32, 255-276. http://doi.org/10.1016/S0048-7333(02)00099-9

Baker, T., \& Nelson, R. E. (2005). Creating Something from Nothing: Resource Construction through Entrepreneurial Bricolage. Administrative Science Quarterly, 50, 329-366. http://doi.org/10.2189/asqu.2005.50.3.329

Barney, J. (1991). Firm Resources and Sustained Competitive Advantage. Journal of Management. 17(1), 99-120.

'This article is (c) Emerald Group Publishing and permission has been granted for this version to appear here (please insert the web address here). Emerald does not grant permission for this article to be further copied/distributed or hosted elsewhere without the express permission from Emerald Group Publishing Limited.'

DOI: http://dx.doi.org/10.1108/JRME-07-2015-0039 
Birley, S. (1985). The role of networks in the entrepreneurial process. Journal of Business Venturing, 1(1), 107-117. http://doi.org/10.1016/0883-9026(85)900102

Bjerke, \& Hultman. (2002). Entrepreneurial marketing: the growth of small firms in the new economic era. Edward Elgar Publishing.

Bjerke, \& Hultman. (2013). The Role of Marketing Rational and Natural Business Start-Ups. In Z. Sethna, R. Jones, \& P. Harrigan (Eds.), Entrepreneurial Marketing: Global Perspectives (pp. 90-115). Emerald Group Publishing Limited.

Bloom, P. N., \& Smith, B. R. (2010). Identifying the Drivers of Social Entrepreneurial Impact: Theoretical Development and an Exploratory Empirical Test of SCALERS. Journal of Social Entrepreneurship, 1(1), 126-145.

Brush, C. G. ., Greene, P. G. ., \& Hart, M. M. (2001). From initial idea to unique advantage: The entrepreneurial challenge of constructing a resource base. Academy of Management Executive, 15(1), 64 - 78. Retrieved from http://connection.ebscohost.com/c/articles/4251394/from-initial-idea-uniqueadvantage-entrepreneurial-challenge-constructing-resource-base

Bruton, G. D. (2010). Business and the World's Poorest Billion- The Need for an Expanded Examination by Management Scholars. Academy of Management Perspectives, 15(August), 6-10. http://doi.org/10.1525/sp.2012.59.1.1

Carson, D., \& Gilmore, A. (2000). MARKETING AT THE INTERFACE: NOT "WHAT" BUT "HOW." Journal of Marketing Theory \& Practice, 8(1), 1. Retrieved from http://connection.ebscohost.com/c/articles/3628034/marketing-interface-notwhat-but-how

Chaston, I. (2000). Entrepreneurial Marketing: Competing by Challenging Conventions (p. 255). Purdue University Press. Retrieved from http://books.google.fi/books/about/Entrepreneurial_Marketing.html?id=TgYSAAA ACAAJ\&pgis $=1$

Dees. (2012). A Tale of Two Cultures: Charity, Problem Solving, and the Future of Social Entrepreneurship. Journal of Business Ethics, 111(3), 321-334. http://doi.org/10.1007/s10551-012-1412-5

Dees, J. G. (1998). The meaning of social entrepreneurship. Innovation, 2006, 1-6. http://doi.org/10.2307/2261721

Defourny, J. (2001). From third sector to social enterprise. The Emersence of Social Enterprise, 1-18.

Desa, G. (2012). Resource Mobilization in International Social Entrepreneurship: Bricolage as a Mechanism of Institutional Transformation. Entrepreneurship:

'This article is ( $)$ Emerald Group Publishing and permission has been granted for this version to appear here (please insert the web address here). Emerald does not grant permission for this article to be further copied/distributed or hosted elsewhere without the express permission from Emerald Group Publishing Limited.'

DOI: http://dx.doi.org/10.1108/JRME-07-2015-0039 
Theory and Practice, 36, 727-751. http://doi.org/10.1111/j.15406520.2010.00430.x

Di Domenico, M., Haugh, H., \& Tracey, P. (2010). Social bricolage: Theorizing social value creation in social enterprises. Entrepreneurship: Theory and Practice, 34(0), 681-703. http://doi.org/10.1111/j.1540-6520.2010.00370.x

Eggers, F. (2010). Grow with the flow: entrepreneurial marketing and thriving young firms. International Journal of Entrepreneurial Venturing, 1(3), $227-244$. Retrieved from http://www.inderscience.com/info/inarticle.php?artid=31024

Eisenhardt, K. M. (1989). Building Theories from Case Study Research. Academy of Management Review.

Eisenhardt, K. M., \& Graebner, M. E. (2007). Theory building from cases: Opportunities and challenges. Academy of Management Journal, 50(1), 25-32.

Ewing, M. T., \& Napoli, J. (2005). Developing and validating a multidimensional nonprofit brand orientation scale. Journal of Business Research, 58(6), 841-853. http://doi.org/10.1016/j.jbusres.2003.09.012

Garud, R., \& Karnøe, P. (2003). Bricolage versus breakthrough: distributed and embedded agency in technology entrepreneurship. Research Policy, 32(2), 277300. http://doi.org/10.1016/S0048-7333(02)00100-2

Gilmore, A. (2011). Entrepreneurial and SME marketing. Journal of Research in Marketing and Entrepreneurship, 13(2), 137-145. http://doi.org/10.1108/14715201111176426

Halme, M., Lindeman, S., \& Linna, P. (2012). Innovation for Inclusive Business: Intrapreneurial Bricolage in Multinational Corporations. Journal of Management Studies, 49(June), 743-784. http://doi.org/10.1111/j.1467-6486.2012.01045.x

Hamel, G., \& Prahalad, C. K. (1993). Strategy as Stretch and Leverage - HBR. Harvard Business Review, 71(2), 75-84. Retrieved from https://hbr.org/1993/03/strategy-as-stretch-and-leverage

Hatton, E. J. (1988). Teachers' Work as Bricolage: Implications for Teacher Education. British Journal of Sociology of Education, 9(3), 337-357. Retrieved from http://www.jstor.org.ezproxy.jyu.fi/stable/1392797?seq=1\#page_scan_tab_conte nts

Hausmann, A. (2012). Creating " buzz ": opportunities and limitations of social media for arts institutions and their viral marketing. International Journal of Nonprofit and Voluntary Sector Marketing, 17, 173-182. http://doi.org/10.1002/nvsm

'This article is $@$ Emerald Group Publishing and permission has been granted for this version to appear here (please insert the web address here). Emerald does not grant permission for this article to be further copied/distributed or hosted elsewhere without the express permission from Emerald Group Publishing Limited.'

DOI: http://dx.doi.org/10.1108/JRME-07-2015-0039 
Hills, B. G. E., \& Hultman, C. M. (2006). Entrepreneurial Marketing. In S. Lagrosen \& G. Svensson (Eds.), Marketing - Broadening the Horizons (pp. 219-234). Studentlitteratur AB.

Hinz, O., Skiera, B., Barrot, C., \& Becker, J. U. (2011). Seeding Strategies for Viral Marketing: An Empirical Comparison. Journal of Marketing. http://doi.org/10.1509/jm.10.0088

Hockerts, K. (2010). Social Entrepreneurship Between Market and Mission. International Review of Entrepreneurship, 8(2), 1-22.

Hunt, S. D. (1997). Resource-Advantage Theory: An Evolutionary Theory of Competitive Firm Behavior? Journal Of Economic Issues, 31(1), 59. Retrieved from http://connection.ebscohost.com/c/articles/9705283915/resourceadvantage-theory-evolutionary-theory-competitive-firm-behavior

Jones, R., Suoranta, M., \& Rowley, J. (2013a). Entrepreneurial marketing: a comparative study. The Service Industries Journal, 33(December 2012), 705719. http://doi.org/10.1080/02642069.2013.740470

Jones, R., Suoranta, M., \& Rowley, J. (2013b). Strategic network marketing in technology SMEs. Journal of Marketing Management, 29(5-6), 671-697. http://doi.org/10.1080/0267257X.2013.797920

Author et al. (2014).

Keller, E. (2007). Unleashing the Power of Word of Mouth: Journal of Advertising Research, 448-452. http://doi.org/10.2501/S0021849907070468

Lampel, Honig, B., \& Drori, I. (2011). Discovering Creativity in Necessity:

Organizational Ingenuity under Institutional Constraints. Organization Studies, 33(1), 153-155. http://doi.org/10.1177/0170840611433379

Lampel, Honig, B., \& Drori, I. (2014). Organizational Ingenuity: Concept, Processes and Strategies. Organization Studies, 35(4), 465-482.

http://doi.org/10.1177/0170840614525321

Lee, H. (2013). BBC News - Why Finnish babies sleep in cardboard boxes. Retrieved January 19, 2015, from http://www.bbc.com/news/magazine-22751415

Lévi-Strauss, C. (1966). The Savage Mind (p. 290). University of Chicago Press. Retrieved from http://books.google.fi/books/about/The_Savage_Mind.html?id=JI6GVFbP9hAC\& pgis $=1$

Lombardo, S., \& Kvalshaugen, R. (2014). Constraint-Shattering Practices and Creative Action in Organizations. Organization Studies, 35(4), 587-611. http://doi.org/10.1177/0170840613517597

'This article is () Emerald Group Publishing and permission has been granted for this version to appear here (please insert the web address here). Emerald does not grant permission for this article to be further copied/distributed or hosted elsewhere without the express permission from Emerald Group Publishing Limited.'

DOI: http://dx.doi.org/10.1108/JRME-07-2015-0039 
Mair, J., \& Martí, I. (2006). Social entrepreneurship research: A source of explanation, prediction, and delight. Journal of World Business, 41(1), 36-44. http://doi.org/10.1016/j.jwb.2005.09.002

Mattson, L. (1997). Relationship marketing' and the "market-as-networks approach" A comparative analysis of two eveolving streams of research. Journal of Marketing Management, 13(5), 447-461.

Miles, M. P., Crispin, S., \& Kasouf, C. J. (2013). Entrepreneurship's relevance to marketing. Journal of Research in Marketing and Entrepreneurship, 13(2), 126136. Retrieved from http://www.emeraldinsight.com/doi/abs/10.1108/14715201111176417

Morris, M. H., Schindehutte, M., \& LaForge, R. W. (2002). ENTREPRENEURIAL MARKETING: A CONSTRUCT FOR INTEGRATING EMERGING ENTREPRENEURSHIP AND MARKETING PERSPECTIVES. Journal of Marketing Theory \& Practice; 10(4), 1. Retrieved from http://connection.ebscohost.com/c/articles/9185712/entrepreneurial-marketingconstruct-integrating-emerging-entrepreneurship-marketing-perspectives

Ostgaard, T. A., \& Birley, S. (1996). New venture growth and personal networks. Journal of Business Research, 36(1), 37-50. http://doi.org/10.1016/01482963(95)00161-1

Penrose, E. (1956). Theory of the Growth of the Firm. Oxford University Press. Retrieved from http://www.oxfordscholarship.com/view/10.1093/0198289774.001.0001/acprof9780198289777

Phillips, N., \& Tracey, P. (2007). Opportunity recognition, entrepreneurial capabilities and bricolage: connecting institutional theory and entrepreneurship in strategic organization. Strategic Organization, 5(3), 313-320. http://doi.org/10.1177/1476127007079956

Prahalad, C. K., \& Ramaswamy, V. (2004). Co-creation experiences: The next practice in value creation. Journal of Interactive Marketing, 18(3), 5-14. http://doi.org/10.1002/dir.20015

Radjou, N., Prabhu, J., \& Ahuja, S. (2012). Jugaad Innovation: Think Frugal, Be Flexible, Generate Breakthrough Growth (9781118249741):: Books (p. 288). Jossey - Bass. Retrieved from http://www.amazon.com/Jugaad-InnovationFlexible-Generate-Breakthrough/dp/1118249747

Rowlatt, J. (2013). BBC News - What India's space scientists and street children have in common. Retrieved January 19, 2015, from http://www.bbc.com/news/magazine-24867914

'This article is (c) Emerald Group Publishing and permission has been granted for this version to appear here (please insert the web address here). Emerald does not grant permission for this article to be further copied/distributed or hosted elsewhere without the express permission from Emerald Group Publishing Limited.'

DOI: http://dx.doi.org/10.1108/JRME-07-2015-0039 
Santos, F. M. (2012). A Positive Theory of Social Entrepreneurship. Journal of Business Ethics, 111(3), 335-351. http://doi.org/10.1007/s10551-012-1413-4

Sarasvathy, S. D. (2001). Causation and effectuation: Toward a theoretical shift from economic inevitability to entrepreneurial contingency. Academy of Management Review, 26, 243-263. http://doi.org/10.5465/AMR.2001.4378020

Schumpeter, J. A. (1934). The Theory of Economic Development: An Inquiry Into Profits, Capital, Credit, Interest, and the Business Cycle (p. 255). Transaction Publishers. Retrieved from https://www.google.fi/books?hl=en\&lr=\&id=OZwWcOGeOwC\&pgis=1

Seelos, C., \& Mair, J. (2005). Social entrepreneurship: Creating new business models to serve the poor. Business Horizons, 48(3), 241-246.

http://doi.org/10.1016/j.bushor.2004.11.006

Seelos, C., \& Mair, J. (2007). Profitable Business Models and Market Creation in the Context of Deep Poverty: A Strategic View. Academy of Management Perspectives, 21(4), 49-63. http://doi.org/10.5465/AMP.2007.27895339

Shaw, E. (2004). Marketing in the social enterprise context: is it entrepreneurial? Qualitative Market Research: An International Journal, 7(3), 194-205. http://doi.org/10.1108/13522750410540209

Srivastava, R. K., Fahey, L., \& Christensen, H. K. (2001). The resource-based view and marketing: The role of market-based assets in gaining competitive advantage. Journal of Management, 27(6), 777-802.

http://doi.org/10.1177/014920630102700610

Stokes, D. (2000). Entrepreneurial marketing: a conceptualisation from qualitative research. Qualitative Market Research: An International Journal, 3(1), 47 - 54. Retrieved from http://www.emeraldinsight.com/doi/full/10.1108/13522750010310497

Thomas, G. M. (2004). Building the buzz in the hive mind. Journal of Consumer Behaviour, 4, 64-72. http://doi.org/10.1002/cb.158

Vasilchenko, E., \& Morrish, S. (2011). The Role of Entrepreneurial Networks in the Exploration and Exploitation of Internationalization Opportunities by Information and Communication Technology Firms. Journal of International Marketing, 19(4), 88-105. http://doi.org/10.1509/jimk.19.4.88

Webster, F. E. J. (1992). The Changing Role of Marketing in the Corporation. Journal of Marketing, 56(4), 1-17. Retrieved from http://www.jstor.org/discover/10.2307/1251983?sid=21105655502963\&uid=5910 312\&uid=62\&uid=3737976\&uid $=27343 \&$ uid $=67 \&$ uid $=3 \&$ uid $=27344 \&$ uid $=2$

'This article is $@$ Emerald Group Publishing and permission has been granted for this version to appear here (please insert the web address here). Emerald does not grant permission for this article to be further copied/distributed or hosted elsewhere without the express permission from Emerald Group Publishing Limited.'

DOI: http://dx.doi.org/10.1108/JRME-07-2015-0039 
Weerawardena, J., \& Mort, G. S. (2006). Investigating social entrepreneurship: A multidimensional model. Journal of World Business, 41(1), 21-35.

http://doi.org/10.1016/j.jwb.2005.09.001

Wei-Skillern, J., Austin, J. E., Leonard, H., \& Stevenson, H. (2007). Entrepreneurship in the Social Sector (p. 424). Sage Publications. Retrieved from http://www.sagepub.com/textbooks/Book230730

Wilson, H. I. ., \& Appiah-Kubi, K. (2002). Resource leveraging via networks by hightechnology entrepreneurial firms. The Journal of High Technology Management Research, 13(1), 45-62. http://doi.org/10.1016/S1047-8310(01)00048-7

Yin, R. K. (2009). Case Study Research: Design and Methods. (L. Bickman \& D. J. Rog, Eds.) (p. 219). Sage Publications. Retrieved from http://books.google.fi/books/about/Case_Study_Research.html?id=FzawlAdilHk C\&pgis $=1$

Zahra, S. a., Gedajlovic, E., Neubaum, D. O., \& Shulman, J. M. (2009). A typology of social entrepreneurs: Motives, search processes and ethical challenges. Journal of Business Venturing, 24(5), 519-532.

http://doi.org/10.1016/j.jbusvent.2008.04.007

'This article is () Emerald Group Publishing and permission has been granted for this version to appear here (please insert the web address here). Emerald does not grant permission for this article to be further copied/distributed or hosted elsewhere without the express permission from Emerald Group Publishing Limited.'

DOI: http://dx.doi.org/10.1108/JRME-07-2015-0039 